\title{
Le Petit Prince: Lessons From a Beloved Fable for Our Current Time
}

\author{
Shaurya Taran, $\mathrm{MD}^{1}$, Allan S Detsky, MD, PhD, CM²*
}

${ }^{1}$ Interdepartmental Division of Critical Care Medicine, University of Toronto, Toronto, Ontario, Canada; ${ }^{2}$ Institute for Health Policy, Management, and Evaluation, and Department of Medicine, University of Toronto; and Department of Medicine, Mount Sinai Hospital and University Health Network, Toronto, Ontario, Canada.

\begin{abstract}
"Good evening," said the little prince politely.
"Good evening," said the snake.

"What planet have I fallen on?" asked the little prince.

"On the planet Earth, in Africa," replied the snake.

"Oh... Then there are no people on Earth?"

"This is the desert. There are no people in the desert.

The Earth is big," said the snake.

The little prince sat down on a stone and looked up at the sky.

"I wonder," he said, "if the stars are lit up so that each

of us can find his own star again. Look at my planet.

It is right above us... But how far away is it?"1
\end{abstract}

e Petit Prince is one of the twentieth century's most widely read fables. ${ }^{1}$ Written in 1943 by the French aviator and novelist Antoine de Saint-Exupéry, it tells the story of a young prince who inhabits a small planet in outer space with his muse, a fragile and dainty rose. The prince loves his rose and goes to great lengths to protect her, but her constant needs prove too much for him to bear. One day he decides to leave her and sets out on a journey across the universe. Along the way he stops at several different planets and interacts with their sole inhabitants, each of whom performs a bizarre and arguably pointless activity. The prince leaves each planet confused and despondent-for no place or person has proven more inspiring than his own planet or rose-until he arrives on Earth, where he meets a snake, a fox, and the novel's unnamed narrator. Their company is a welcome relief for the travel-weary prince, who learns important lessons about love, friendship, and "matters of consequence." Toward the novel's end, the snake promises to deliver the little prince home if he allows himself to be bitten. The prince obliges in order to be with his rose, and he soon disappears. The story concludes with the narrator looking up at the stars, wondering if the prince is somewhere among them.

One interpretation of Le Petit Prince is that life is more beautiful when the things that give it meaning are recognized and cherished, but there is a heavy irony behind this theme. The story was published during one of the lowest

*Corresponding Author: Allan Detsky, MD, PhD, CM; Email: Allan.Detsky@ siniahealth.ca; Twitter: @Adetsky.

Published online first April 27, 2021.

Received: April 21, 2021; Accepted: April 21, 2021

๑ 2021 Society of Hospital Medicine DOI 10.12788/jhm.3640 points in the Second World War, when France was still in the grips of its German oppressors. Saint-Exupéry himself had fled to the United States years earlier and composed Le Petit Prince during a time of personal upheaval. In short, nothing about the context of the book's birth seemed to inspire its rosy message.

Now, almost 80 years after the first publication of Le Petit Prince, we find ourselves in a similarly jarring and unpredictable time. As calamitous global events unfold around us, it is difficult not to feel overwhelmed. For healthcare workers, the crush of patient care has made us feel vulnerable-first to a virus that might infect us and our loved ones, and second, to the overwhelming sense of despair when caring for patients who ultimately die despite our best efforts. Pandemics are a time of physical and social disruption, and while it has been 100 years since we experienced one like this, they are a repeated part of the history of life on our planet. What would the little prince see if he landed in our clinics, hospitals, nursing homes, testing centers, or vaccination facilities today? Would he observe patients saying good-bye to family members on tablets and cell phones because their loved ones are not allowed to visit in person? Would he see healthcare workers struggling to resuscitate dying patients in a crowded emergency department or intensive care unit? Would he see long lines of cars filled with people waiting for tests or vaccines? Would he see government officials and public health workers agonizing over decisions about steps that could reduce spread but impose economic hardship on many?

There has been much debate about whether Le Petit Prince is a children's story or a message for adults disguised as a children's fable. Perhaps the answer is that it is both, for many children's stories were actually written for adults. Despite the fragility and delicacy of the book, there is clearly a haunting and deep irony inherent in what it is, in effect, a most savage critique of the world at war.

Two themes that emerge in the novel resonate widely now: isolation and death. Each character the little prince meets is alone, mirroring the long periods of social distancing we have experienced over the past year. And while death is never explicitly mentioned in the book, it seems to be lurking throughout, especially when the prince disappears from Earth after being bitten by the snake. Currently, we have almost become numb to the reported daily death counts-each one alone would have evoked outrage in more usual times. One might imagine that Saint-Exupéry wrote this fable in part to help people cope with the deaths of their loved ones. 
And when you are comforted (time soothes all sorrows) you will be happy to have known me. You will always be my friend. You will want to laugh with me. And from time to time you will open your window, so, just for the pleasure of it ... And your friends will be astonished to see you laughing whilst gazing at the sky! And so you will say to them, "Yes, stars always make me laugh!"

Over the past year, both authors of this essay have seen people turn to Le Petit Prince to cope with death. One of us observed a daughter reading the book to her mother at her intensive care bedside on the day she died. The other received a copy as thanks from the wife of a young man who died after 18 months of punishing chemotherapy for sarcoma. Inside the cover was a picture of her husband and the inscription, "Please share this book with someone you love-it's meant to be read out loud —and remember James." And so I did, with my grandson Sebastian, who listened to the story with the imagination, wonder, and curiosity of a 6-year-old - he had many questions.

Perhaps the fable that has comforted our patients and their families during their time of despair can do the same for us. Like the prince, who returns to his rose after a difficult journey, we might find solace in the people and things that give our lives their deepest meaning. Thereafter, we might return, rejuvenated, to the clinics, emergency departments, and inpatient wards where our daily work must continue. While the scale of the problems around us makes it feel like any step we take towards preserving our hope will be moot, Le Petit Prince teaches us there is value in making the effort. And there is even a chance that we will find, to our surprise, and against our more cynical judgment, a small rose pushing itself up towards the light.

\section{Acknowledgments}

The authors thank Rita Charon (Columbia University), Pam Hartzband (Harvard University), Raphael Rush (University of Toronto), and Emily Silverman (University of California San Francisco) for their comments on earlier versions of this essay. None were compensated. We thank Sebastian, James' wife, and our other patient's daughter for giving permission to include them in the story.

Disclosures: Dr Detsky reports that he will receive stocks in the future from Bindle Systems for serving on the company's Scientific Advisory Board; receiving consulting fees from Telus for serving on the company's Medical Advisory Committee for Pandemic Planning; and owning stock in Pfizer, Astra Zeneca, and Johnson \& Johnson.

\section{Reference}

1. de Saint-Exupéry A. The Little Prince. Harcourt Brace; 1961. 